\title{
先天異常告知後の支援について
}

\author{
斉藤 吉人
}

要 約：現在, 先天異常の早期発見は出生前や出生直後の段階にまで進んでいる。こうした 状況の下, 北九州地域では口唇口蓋裂のある新生児とその家族に対し, 歯科医師と言語聴覚士 が産科医師・新生児科医師と連携して, カウンセリングを含む家族支援を行ってきた. 現在で は, あらゆる先天異常を視野に入れた支援活動を展開中である.これらの家族支援においては, 先天異常のある子どもの療育を担っている言語聴覚士や小览のリハビリテーションに従事する 人久，すなわち療育者が行う療育的支援が重要であることを述べた。そして，この療育的支援 の充実には医療と療育の連携が必要であることを強調した。

索引用語：先天異常，告知，家族支援，療育的支援，医療と療育の連携

\section{Support after Disclosure on Congenital Disorders}

\author{
Yoshito Saito
}

\begin{abstract}
Presently, early detection of congenital disorders has made much progress, reaching the stage before and immediately after birth. Against this backdrop, in the Kitakyusyu area dentists and speech-language-hearing therapists have worked in close cooperation with doctors in the fields of obstetrics and neonatal medicine to provide family support and counseling for newborns with cleft lip and palate and their families. Currently this support activity has been taking a new turn involving all congenital disorders.

In these family support activities, the importance of child rehabilitation support conducted by specialists, including speech-language-hearing therapists, has been noted. In particular it has been stressed that for further substantiation of such support activities, medical treatment should be linked with child rehabilitation.
\end{abstract}

Key words: congenital disorders, disclosure, family support, rehabilitation support, link between medical treatment and child rehabilitation

\section{ロ唇口蓋裂から始まった家族支援}

北九州市立総合療育センター(以下，当センターと 略)の家族支援の活動は 1987 年，口唇口蓋裂児(以下， CLP 児と略)を対象として開始されている ${ }^{1,2)}$. CLP 览
誕生直後, すなわち出生日もしくは翌日に, 歯科医師・ 歯科衛生士・言語聴覚士が支援チームを組織し, 産科・ 新生児集中管理室(以下，NICU と略)を訪問し，哺乳 障害への対応と上顎骨発育誘導のための Hotz 型人工 口蓋床(以下, Hotz 床と略)の作製・適合を行う。表 1

北九州市立総合療育センター訓練科言語聴覚係：干802-0803 福岡県北九州市小倉南区春ヶ丘 10-2

Kitakyusyu Rehabilitation Center for Children with Disabilities: 10-2 Harugaoka, Kokuraminami-ku, Kitakyusyu City, 
表 1 出生時の医療的対応と家族への支援

1. 子どもとの対面と情報収集, 上顎顎堤と口蓋の印象採得 - 裂形, 合併症, 命名, 家族の状況の確認

・家族の反応や質問など

・Hotz 床製作のための印象採得

2. 誕生の祝福

3. 事実を伝える

4. 予測される問題の整理と解決への道筋

・口唇口蓋裂とは何かの理解

•Hotz 床の働き，口唇・口蓋形成術，修正術，歯列矯正 など

・構音障害，言語訓練，訓練成績，自然な関わり，聴覚 スクリーニングなど

5. ピアカウンセラーの紹介

6. いま，家族として大切なこと

・前向きな子育て・あたりまえの子育て

・隠さない子育て

に出生時の医療的対応と家族への支援の内容を示す.

\section{1 . 対面と情報収集，顎堤・口蓋印象の採得}

最初に行うのが誕生した CLP 新生児との対面であ る. 裂形や合併症の有無の確認, 命名の有無を確認す る。また産科・新生児科主治医や担当看護師の話し， カルテ情報などから家族の状況を収集する.引き続き， 口唇裂単独例を除くほとんどのケースでは Hotz 床の 作製を行うため，上顎顎堤と口蓋の印象採得を行う。

\section{2 ，誕生の祝福}

その後, 主治医と相談のうえ，「何をどの順序でどこ まで話すか」を決め，歯科医師と言語聴覚士が家族と の面会に臨む．面会はできるだけ静かな部屋で，また 他の家族の目に触れない場所を提供してもらう。帝王 切開分婏などで母親がまだ起き上がれない状況ではべ ッドサイドで行うこともまれではない．面会でまず行 うのが誕生の祝福である，家族，特に母親は大変なシ ヨックを受けている．出産の喜びと安堵が罪責感と今 後への不安という苦しみに一変している．障害のこと のみに意識が向き，かけがえのないいのちが誕生した という祝福されるべき事実が忘れ去られている。医療 関係者もしばしば病や障害を診るという立場から，誕 生の祝福を忘れている。こうしたことから面会の冒頭 では，必ず「ご出産・お誕生おめでとうございます.」 と祝辞を述べ，新しいいのちの誕生への祝福と，療育 者としてご家族の立場に共感し，これから継続して支 援していくことの表明を行う。

\section{3。事実を伝える}

ほとんどのケースで，「口唇口蓋裂」とは家族が初め て耳にする言葉である，口唇裂は確認できても口蓋裂 は簡単に目にすることはできない。また，裂形やその
拡がりは一人一人が異なる。したがって，ここでは歯 科医師の診察で得た情報を基に，口唇や口蓋がどのよ うな状態にあるのか，その客観的事実を伝え，事実と して理解することの大切さを話す。口腔模型や他の CLP 览の顎堤・口蓋印象なども用い，専門用語の使用 はできるだけ控え，わかりやすく説明する。

\section{4. 予測される問題の整理と解決への道筋}

家族は先の見えない不安な状況におかれている。 るいはインターネットや医学書・専門書を通じて不適 切なものも含む過度の情報に晒され，混乱した状況に 追い込まれている.ここでは，CLPの裂型により予測 される問題を専門的な立場から整理し，その一つひと つに具体的な解決の道が用意されていることを伝え， 少しでも家族の安心を得ることを目的に話しをする。 術前・術後の写真なども用いながら，平易な言葉で説 明する。

\section{5.ピアカウンセラーの紹介}

当センターでは CLP 児を出産し子育て体験を持つ 母親たちによるボランティア組織を組織化している. 医療・療育関係者の話しとは異なる次元で，手術を乗 り越え子育てを実践してきた母親に出逢うことは大き な安心をもたらすものと考えている，両親の希望を確 認したうえで紹介する。

\section{6.いま，家族として大切なこと}

最後に，いま，家族として何が大切かを話す。一つ 目は後ろを振り向かない「前向きな子育て」である. 確かにCLP がなかったらと願うのは自然なこころの はたらきである。しかし，現実にはCLP があったので あり，なかったらと望むのは子どもの存在自体を否定 することである，後ろを振り返って，何が原因かを追 求しても，子どもにとって有益な答えは何も得られな い. 子どもにCLPがあったのは「誰の責任でもない」 ということを家族全員で共有し，協力して子育てを開 始することが求められている。二つ目は「あたりまえ の子育て」である.CLP があったことは「特別な子育 て」をする責任と義務が両親に課せられたことを意味 するものではない。むしろ，自然な親子としての愛着 関係をまず育むことが優先されなければならない。両 親にしかできないスキンシップを中心とした愛情深い 子育てを始めることが何よりも必要である。三つ目は 「隠さない子育て」である。現代の最高の医療技術をも つてしても手術の跡は瘢痕として残る。つまり成長と ともにいずれは他の子どもたちから傷の指摘を受け， また子ぞも自身が気づくようにもなる。両親が CLP を他人の目に触れてはならないもの，隠さなければな 


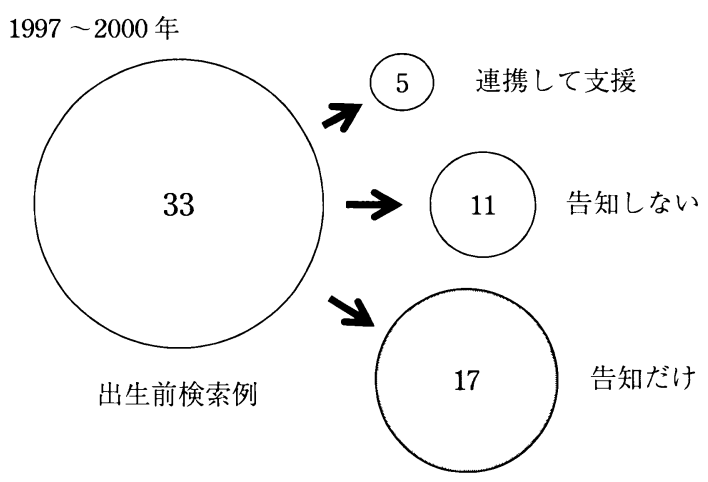

図 1 出生前診断後, 産科医師の家族に対する対応

らないものとしてネガティブに受け止め育てていくと すれば，両親が自分を劣った存在として見ているとい う誤ったメッセージを子どもに伝えてしまうことにも なりかねない.また，目の前の問題として，口唇・ロ 蓋形成術という全身麻酔による手術を乗り越えていか なければならない.できるだけ多くの家族・友人・知 人の支援を必要としている。このような支援は隠す子 育てからは得ることができない.

\section{出生前診断の状況}

現代の医療は先天異常や遺伝性疾患の早期発見を出 生前の胎児の段階で可能としている。このうち, 超音 波画像診断 (以下, USD と略) は超音波を母体腹部に当 て胎児の画像所見を得るもので，わが国では妊婦検診 で日常的に行われている診断法である。最近では画像 解析能の向上により CLP も容易に診断されるように なり, 出生前に告知を受けた家族への支援要請も経験 してきた。しかし，ここには医療の深刻な問題があ る3). 図 1 は, 1997 年から 2000 年までの 3 年間の調査 で，私たちが後に出会うこととなった CLP览の家族 のうち, USD により出生前の段階で口唇裂を見つけた 産科医師がその後にとつた対応を示す ${ }^{4)}$. 当時, 出生前 に口唇裂を発見された 33 家族中, 家族への告知後に出 生前の支援の連携を筆者らと取れたのは 5 家族にしか すぎなかった. 半数以上の 17 家族は病名の告知と手術 で解決するという情報だけで，その後の長い不安な妊 娠期間を過ごさざるをえなかった。はたして，医療情 報の伝達だけで十分な家族のケアは可能だろうか？

\section{それぞれの家族への支援 ${ }^{5-7)}$}

\section{1. 出生前診断で障害告知を受けた CLP 単独例の} 家族

産科医師はすでに妊娠 20 週でUSD により口唇裂 の存在を疑っていたが, 22 週ではよくわからず妊娠 24
週にいたり，やはりその存在を確信した。里帰り出産 の可能性もあると告げられた医師は，今しか時期はな いと判断し，夫婦に病名を告知した。直後に私たちに 支援の要請があり歯科医師と言語聴覚士が産科医院に 出向いた。夫婦にとっては待ち望まれた初めての子ど もである.いつものように祝福の言葉を伝え, 画像所 見から予測された片側性口唇口蓋裂を前提に説明をし た。 夫婦の表情には告知を受け不安な表情も読み取れ たが，同時に筆者らの話を真剣に受け止めようという 前向きな姿勢も感じられた。話が進むなかで母親はよ く領き，ときおり笑顔も見られていた。最後には「今 日はお話しが聞けて安心しました」と二人とも笑顔で 挨拶された。祖父母が望めば再度話しをすること, ピ アカウンセリングも可能なことを伝え，その日は帰宅 した.

しかし，翌週，医師からわれわれに連絡が入った。 「困ったことが起きた。母親から中絶してくれという電 話が入った.」とのこと. 急遽, 2 回目の支援を行った. 母親は異常に憔悴していた。父方祖母の言葉である。 「いのちの大切さは十分理解しています.でも，母親の 状態を見ると母体のほうが心配です。今からでも何と かなりませんか? 」母方祖母の言葉である。「喉の奥が 割れていて言語障害のある男性を知っています。その ことを娘に言いました，娘は食事も喉を通らないので す. 母体を守ることが先でしょう.」この間, 父方祖父 はまったくの無言であった。翌日父親から電話が入り 「生むことに決めた.」とのことで，妊娠は継続される ことになった，翌週，自宅を訪問した際，母親は「主 人は仕事で夜遅いから一人で何でもやらないといけな い. 不安が重なったのです.」と述べている.

その後も母親は動摇を繰り返し, 夜間の不眠と徘徊 があるとのことだった，筆者らは以前から協力関係に ある産科医院に相談し, 転院と一時入院を勧めた。満 期産・自然分婏で誕生. 同日, 支援に向かった. 誕生 の祝福を述べた筆者らに母親を除く家族全員が笑顔で 応えてくれた。しかし, 誕生直後, 母親は実際には子 ぞもを抱けず授乳もできなかった。 また，私たちに会 おうとはしなかった. ところが，それから 1 力月後, 当センター外来に来所した母親と母方祖母が満面の笑 みで「生ませてくださって本当に感謝しています.」と 語ってくれたのである。

以上のように, この家族は告知と支援の後, 潜在的 にあった家族の問題が顕在化し，それに対する対応に 力を尽くした家族であった。しかし，出産にいたるま での歩みを，困難ではあっても，ともにし続けたこと 
と産科医院のスタッフの献身的な対応が，最終的には 誕生の喜びへと繋がった家族であったと考える。

こうした支援の活動を通して，筆者らは産科や NICU との広範なネットワークを形成してきた。この ネットワークの地理的範囲は北九州市を中心に遠くは 大分県宇佐市，山口県岩国市にまで及んでいる。また 支援の対象は, 必然的にこれらの産科や NICU で出生 する他の先天異常の子どもと家族へも求められるよう になってきた。

\section{2．ダウン症児の出生した家族}

ある総合病院外来婦長より連絡があり，ダウン症児 を出生した母親の育児不安が大変大きく, 療育関係者 との面会を強く望んでいるとの連絡を受けた，男児で 第 2 子， 21 トリソミーのダウン症児である.心疾患の 合併症があり主治医から手術の必要性が伝えられてい た。

面会の際の母親の訴えは次のようなものであった. 父親は育児に対して大変協力的で熱心である.ダウン 症児を出生したということでインターネットなどを通 じさまざまな医学的情報を入手し母親に与えている. しかし，それらの情報を読むと多くの合併症やその予 後が記載されていて，この子が無事に育つのか大変不 安だ。また，姉は普通の育児で順調に育ったが障害の あるこの子をどう育てれば良いのかわからない。そし て，ダウン症児を育てた母親にぜひ会っていろいろな 話しを聞きたい。

筆者らは母親の訴えから次の 2 点を問題として考え た。すなわち，(1)合併症を中心として過度の医学的情 報が本児の実際の状態とは無関係に未整理なかたちで 提示され，母親の不安がかえって増強されている。 ま た, ダウン症のある人の成長・発達・生活の様子など 必要な療育的情報が不足しており，母親が育児への見 通しを持てなくなっている。(2)さらに，療育機関を紹 介されながら，同時に母親としての自覚も求められ， そのことが責任感の強い母親の気持ちをさらに落ち込 ませているようである.

以上のことから筆者らは以下の 4 点を母親に提示し た. (1)合併症はあるものの，母乳で哺乳できて扔り比 較的順調に育っていることを知ってほしい．専門的情 報は直接得るのではなく専門家による適切な取捨選択 を経たものを専門家から得てほしい. (2)本児をダウン 症児として育てるのではなく，あなたの家族にもたら された新しい「いのち」として，あなたの子として育 ててほしい. (3)そして，ピア・カウンセラーを紹介し， (4)時期を見て当センターを受診してほしい。その後,
本児は心疾患の手術も無事終了し，当センターでの療 育を受け，現在は特別支援学級に在籍し，元気に学校 生活を送っている。

ダウン症児が出生したショック期にある家族，特に 母親が子育ての歩みを始めるためには，障害を持つ子 の「いのち」の誕生を肯定的に受け止める周囲の関係 者の態度がきわめて重要と考える。しかし，産科や小 児科で行われることの多い診断告知では，内容が医療 的情報に偏りがちで，障害を持ちながらも意義ある人 生を送っている多くの障害のある人々の情報，すなわ ち療育的情報が不足しがちである。そこに，医療サイ ドでの診断告知に引き続くかたちで，療育側からの支 援やピア・カウンセリングが行われる意義があると考 える ${ }^{8}$.また，筆者らは家族支援の一環として，同じ状 況におかれた家族の集いの場「ダウン症等支えあいの 会」も組織化している ${ }^{9} .3$ 力月に 1 回程度の例会を開 催し，学習会や互いの子育ての近況報告などをしてい る。さらに，ダウン症児が出生した家族向けに，パン フレットも作成している.ダウン症のある人の成長・ 発達を紹介しながら，これからの育児への見通しが持 てるょうにと作成した。そして，これらの活動のなか から，ピア・カウンセラーとしてダウン症児の出生し た家族を支援してくださる家族が増えている.

3. 出生前に先天異常の告知を受け, 生後 3 力月に 死亡した 13 トリソミー児の家族

染色体異常のある子どもたちのなかには重篤な合併 症を伴い，生命予後の不良な医学的には「重症障害新 生児」と呼ばれる子どもたちがいる. 表 2 は北九州で 活動している，子どもを亡くした親と家族を支える会 「星の会」が残された家族を対象に行ったアンケートの 一部である ${ }^{10)}$. 家族は何らかの心残りを抱いているが, とりわけ子どもが亡くなるまでのケア，すなわちター ミナル・ケアに扔いて，「一緒の時をもっと持ちたかっ

表 2 子どもの死後の心残りの内容（複数回答）

\begin{tabular}{lc}
\hline \multicolumn{1}{c}{ 選択内容 } & 回答数 \\
\hline 一緒の時をもっと持ちたかった & 9 \\
介護を直接もっとしたかった & 4 \\
末期医療や看護の説明が不十分 & 2 \\
末期の介護に不満がある & 2 \\
自分の態度・行為が良かったのか & 2 \\
死因が納得出来ない & 1 \\
その他 & 1 \\
\hline
\end{tabular}

7 家族のうち,子どもの死後心残りがあると答えた 6 家族 11 人 の回答を集計した。(アンケート調査*) *重症障害新生児の夕 一ミナルケアとその家族のグリーフケア，武田康男，脳と発達 $35(3): 34-38,2003$. 
た」「介護を直接もっとしたかった」など家族としての ケアに悔いを残している.

第一子女览で, 在胎 35 週, 産科医師汁両側性 CLP 疑い, 子宮内発育不全, 心疾患疑い, 18 卜リソミ一疑 いの診断を行った。医師は告知前に筆者らに連絡し， 相談のうえ，35 週にCLPのみを告知した。筆者らは 36 週から支援を開始した。里帰り出産で, 参加したの は母親と母方の祖父であった。「吃驚されたでしょう」 の言葉に母親は涙を流した。祖父は「口唇口蓋裂は知 り合いにもいるので心配していない。むしろ, 発育不 全などその他のことが心配.」と言い，涙を流し続ける 母親に「泣くんじゃない.どういう状態があろうとわ れわれの注ぐ愛情の重さに変わりはない.」と言葉をか けた。

出産直前, 周産期センターに入院し心疾患の告知を 受け，この時点で羊水検查を钦められたが，祖父はそ れを断った。母親は分娩台に上がる前もそして出産直 後も筆者らへの連絡の有無を医療スタッフに確認し, 救いを求めた。出生時診断名は 13 トリソミー, 両側性 CLP, 心疾患 (両大血管右室起始症-手術不可), 生命 予後 2 力月であった。

生後 1 力月, NICU 内で㩁乳を注入されていただけ の子どもに療育的ケアとしてロ腔ケアを行い，母親は 母乳を指で与えた。療育的ケアとは口腔ケアや食事の 共有，前言語期のコミュニケーション指導などを通じ て, 子どもと家族の関係性を育むことを意図したケア である11)(図2)。

その後, 生後 2 力月, 心不全を発症, 主治医に生命 予後 10 日と告知された。母親は泣きながら「何をした らいいんですか？」と電話をかけてきた。筆者らは再 度療育的ケアを行った。とって抒きの想い出を語って あげてという筆者らの勧めに対し，両親は結婚式で制 作した CD の曲を NICU 内で子どもに聴かせた。子ど もは生後 3 力月で心不全により死亡している。後日, 母親から書簡を受け取った。そこには，現在は亡くな った子どもと両親の家族三人で暮らしていること，親 としてできることを教えてもらったことへの感謝の言 葉が書かれていた。

\section{ま と め}

医師に上る先天異常告知後の家族支援の実践につい て報告した。この家族支援においては, 先天異常のあ る子どもの療育を担っている言語聴覚士や小児のリ八 ビリテーションに従事する人久すなわち療育者が行う 療育的支援が重要であることを述べた。この療育的支

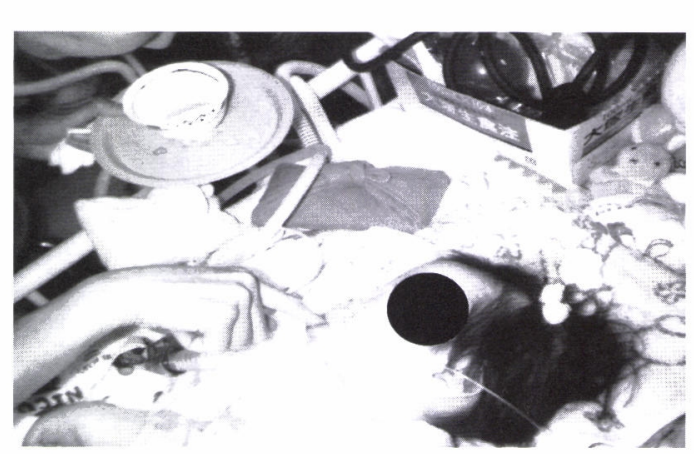

家族との食事の共有

(同じ食事は家族の始まり)

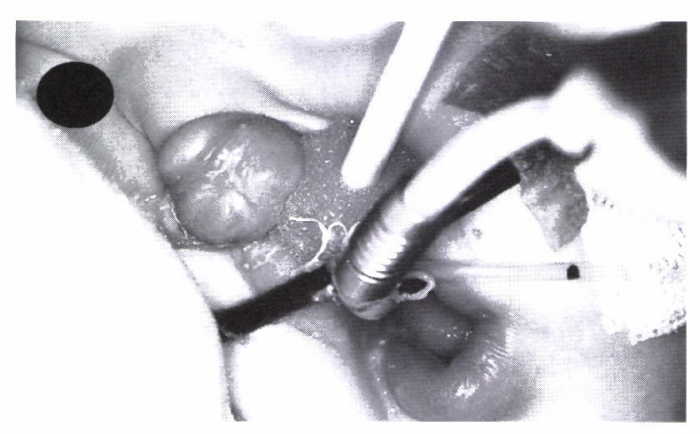

家族によるロ腔ケア

（口腔ケアは，親だからできる関わり)

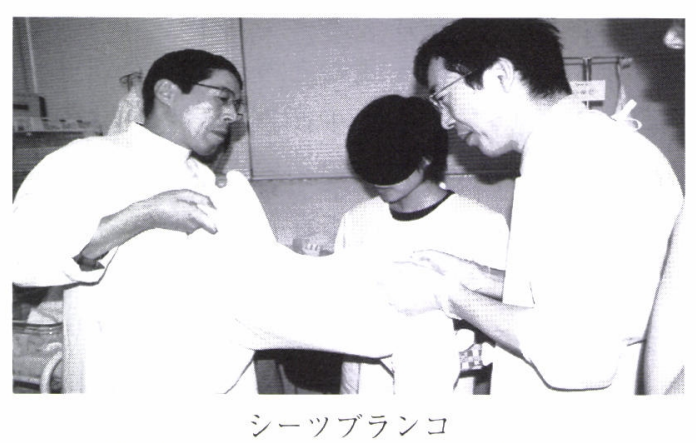

(親子の始まりのコミュニケーション)

図 2 療方的ヶア

療育的ケアの具体例. 生後 1 力月療育的ケア (父親も参加). NICUにてロ腔ケア・乳を飲む.

援には先天異常のある子どもの成長・発達・人生など の療育的情報, 同じ状況におかれた家族が行うピア・ カウンセリング， 口腔ケアや前言語期のコミュニケー ション・ケアなどの療育的ケアが含まれている。そし て,このような療育的支援の充実には医療と療育の連 携が必要と考える。

\section{文献}

1）武田康男：口唇口蓋裂児とその家族の受容支援，障害児歯 科の新しいアプローチ一先天異常児と关の家族の受容支援 一。肾歯科臨床，9(5)：77-86, 2004.

2）齐藤吉人：地域の療育センターの立場から、シンポジウム III, 言語聴覚士のあり方一小览の言語㯖覚領域の現状と課 題一. 第 8 回日本言語聴覚学会抄録集 : 79, 2007. 
3）山中美智子：一人歩きする出生前検査, 産科における超音 波検査の問題. Sexual Science, Medical Tribune Online Magazine, July, 2001.

4）武田康男, 小池多賀子, 竹邊千恵美, 他：口唇口蓋裂の出 生前診断と出生前カウンセリング. 小児歯誌, $39 ： 966-973$, 2001.

5）斉藤吉人, 武田康男, 金丸望美: 出生前診断に対する療育 者としての関わりー2 家族の経験から一.第 12 回出生前診 断研究会抄録集：8，2005.

6）斎藤吉人, 武田康男 : 先天性の障害のある子どもが出生し た家族へのカウンセリング. 言語聴覚療法, 16(1) : 106, 2000 .

7）斎藤吉人：NICU で行うコミュニケーション・ケア．言語 聴覚研究，3(2)：82-84，2006.

8）金丸望美：療育一出生時. 言語聴覚療法臨床マニュアル改
訂第 2 版 (小寺富子監修), 協同医書, 東京, 100-101 頁, 2004.

9）斉藤吉人：先天異常の告知と家族支援. 改訂言語発達障害 II, 言語聴覚療法シリーズ 11 (斉藤吉人編著), 建帛社, 東 京, 90-95 頁, 2007.

10）武田康男：重症障害新生児のターミナルケアとその家族の グリーフケア. 脳と発達, 35(3) : 34-38, 2003.

11）武田康男：ターミナルケアとグリーフケア. 小児科診療, $67(2): 248-253$, 2004.

別刷請求先：干802-0803 福岡県北九州市小倉南区春ヶ丘 $10-2$ 北九州市立総合療育センター 訓練科言語聴覚係 斉藤吉人 